\title{
Behaviour of durum wheat cultivars towards deoxynivalenol content: A multi-year assay in Italy
}

\author{
Tiziana Amoriello, ${ }^{1}$ Andreina Belocchi, ${ }^{2}$ Fabrizio Quaranta, ${ }^{2}$ Cecilia Ripa, ${ }^{2}$ Francesca Melini, ${ }^{1}$ \\ Gabriella Aureli ${ }^{2}$ \\ Council for Agricultural Research and Economics, ${ }^{1}$ CREA Research Centre for Food and Nutrition; ${ }^{2}$ CREA \\ Research Centre for Engineering and Agro-Food Processing, Rome, Italy
}

\begin{abstract}
The deoxynivalenol (DON) occurrence in durum wheat (Triticum durum Desf.) kernels is a key food safety issue, hence more and more attempts have been made to increase the availability of resistant cultivars. Within this framework, this work focused on the analysis of the behaviour of several durum wheat cultivars widely grown in Italy in relation to the level of deoxynivalenol contamination in whole milled kernels. A total of 2844 samples were submitted for deoxynivalenol analysis by enzyme-linked immuno-sorbent assay. The statistical analysis by generalised linear models provided a trend ranking of durum wheat cultivars on the basis of the deoxynivalenol contamination level, depending on each cultivation area assayed. This study provided a better understanding of cultivar susceptibility to mycotoxin accumulation in grains. The role of the factor cultivar has clearly emerged. However, other environmental factors, such as growing area, have a great influence on the DON concentration levels in the cultivars tested.
\end{abstract}

\section{Introduction}

Deoxynivalenol (DON) is the most widespread mycotoxin in

Correspondence: Gabriella Aureli, Council for Agricultural Research and Economics, CREA Research Centre for Engineering and AgroFood Processing, via Manziana 30, 00189 Rome, Italy.

E-mail: gabriella.aureli@crea.gov.it

Key words: Deoxynivalenol; durum wheat; Fusarium; generalised linear models; mycotoxin.

Acknowledgments: the authors acknowledge Mauro Fornara, Valerio Mazzon, Alessandra Arcangeli and Roberto Mortaro for technical support. This work was carried out in the frame of the projects MICOCER and MICOPRINCEM supported by the Italian Ministry of Agricultural, Food and Forestry Policies and coordinated by the Council for Agricultural Research and Economics (CREA).

Received for publication: 3 August 2016.

Revision received: 29 June 2017.

Accepted for publication: 1 July 2017.

CCopyright T. Amoriello et al., 2018

Licensee PAGEPress, Italy

Italian Journal of Agronomy 2018; 13:817

doi:10.4081/ija.2017.817

This article is distributed under the terms of the Creative Commons Attribution Noncommercial License (by-nc 4.0) which permits any noncommercial use, distribution, and reproduction in any medium, provided the original author(s) and source are credited. small grain cereals; it is mainly produced by toxigenic strains of Fusarium graminearum and Fusarium culmorum, which are the most important causal agents of fusarium head blight (FHB) disease. DON belongs to the type B group of trichothecenes, which are largely encountered in cereal crops, and the action of this mycotoxin as a virulence factor during fungal pathogenesis is well-known (Arunachalam and Doohan, 2013; Audenaert et al., 2013). Trichothecenes are a large family of chemically related toxic fungal compounds mainly produced by Fusarium spp. in cereal grains. These mycotoxins have several toxic effects on eukaryotic cells, including inhibition of protein, DNA and RNA synthesis, increase of the permeability of the intestinal epithelial layer (Yazar and Omurtag, 2008; Gauthier et al., 2013; Antonissen et al., 2014; Pinton and Oswald, 2014). DON may have an emetic effect, but also an immunosuppressive, with the latter also representing a risk for human health (Maresca, 2013; SCF, 2002). Resistance to DON is also considered an important aspect of resistance to FHB (Rocha et al., 2005; Walter et al., 2015).

DON is a powerful tool for $F$. graminearum to grow within the host tissue; the wheat plant can, nevertheless, employ detoxification mechanisms to block the adverse effects of the mycotoxin. Indeed, in addition to the resistance mechanisms that determine the severity of FHB attack on the wheat plant, other mechanisms may influence DON content in kernels, e.g., DON degradation or conjugation and tolerance (Ji et al., 2015). In particular, DON binds covalently to hydrophilic molecules, such as glucose and glutathione (Audenaert et al., 2013; Cirlini et al., 2014).

Several studies are available in literature and report positive correlations between disease incidence and mycotoxin accumulation; however, this issue might be more complex due to a not always positive and significant relationship between wheat varieties, exhibiting high resistance to FHB, and low detected DON levels (Boutigny et al., 2008). Recently, several breeding attempts have been made to combine resistance to pathogen development and resistance to mycotoxin accumulation; however, obtaining new genotypes that are suitable to reduce the level of kernel contamination, and hence limit the risk of human and animal exposition upon food consumption keeps being a major challenge. The complex bases of wheat resistance to FHB are not yet fully understood, however it is known that it is controlled by multiple genes and characterised by large genetic variation. Several studies have been so far successfully carried out to identify traits involved in FHB resistance in soft wheat (Triticum aestivum L.); whereas the sources of FHB resistance in durum wheat (Triticum durum Desf.) have not been fully identified yet (Buerstmayr et al., 2009, 2012; Jauhar and Peterson, 2009; Lionetti et al., 2015; Ruan et al., 2012). Durum wheat is by far more FHB-susceptible than soft wheat, and its susceptibility to FHB disease and mycotoxin accumulation in kernels is of particular concern in Italy because of its key role in pasta production (Bottalico and Perrone, 2002; Boutigny et al., 2008; Foround and Eudes, 2009). 
This work aims at examining the behaviour of several durum wheat cultivars grown in a multi-year period in Italy in relation to deoxynivalenol content detected in kernels. Moreover, it assesses the geographical influence leading to significant genotype-by-area interaction.

\section{Materials and methods}

\section{Samples}

A total of 2844 durum wheat grain samples, obtained from both varietal trials (Quaranta et al., 2013) and farms, were collected 2006 to 2014 .

Samples coming from experimental trials were collected within the Italian durum wheat network. The trails were conducted according to the best agronomic practices, most in use in the different cultivation areas, and did not include fungicide treatments for controlling FHB. The incidence of wheat as a previous crop was around $15 \%$ of total samples, but it was not an experimental factor. Each trial was carried out according to a randomised complete block experimental design (RCBD) with three replications $\left(10 \mathrm{~m}^{2}\right.$ plots); the same protocol was used for both year and location. Subsequently, grains from the three-replication plots were bulked and a representative whole grain subsample of about $0.5 \mathrm{~kg}$ was taken for milling. Regarding the sample obtained from farms at harvest time, grains were randomly collected from each cultivar trial: after homogenisation, one sample of about $5 \mathrm{~kg}$ was taken. A subsequent random subsample of $0.3 \mathrm{~kg}$ was taken and submitted to milling operation before analysis. The farms in each Region were chosen by experts from local Institutions and were representative of the local durum wheat cropping system. All sampling operations were substantially based on the criteria of representativeness laid down by the European legislation (EU Commission Regulation No. 401/2006; European Commission, 2006b).

The collection of samples took place in different parts of Italy ( 8 areas) which are classified as durum wheat growing areas: i) North; ii) Centre-East; iii) Centre-West; iv) Central Apennines; v) Southern Apennines; vi) Southern Adriatic Ionian coast; vii) Sicily; and viii) Sardinia (Figure 1). These areas were identified and selected on the basis of criteria, such as geographical position (North, Centre, South and islands), altitude (plain, coast, Apennines), and distance from the sea. These criteria contribute, in fact, to influencing seasonal temperatures, rainfall amount and distribution. To verify possible differences among wheat cultivars grown in different areas and years, samples were grouped in two sub-datasets, and comparisons were made. Dataset A included 1403 durum wheat samples, collected over the three-year period 2012-2014, and comprised 16 cultivars widely grown in Italy. The second dataset (dataset B) comprised 2080 samples of durum wheat, obtained from 7 out of the 16 cultivars and covering a wider time span than dataset A (2006-2008; 2011-2014), for a total of seven years. The seven cultivars were selected because they were constantly available over the seven years. The choice to split the whole dataset in two sub-datasets (A and B) arose from the need to group the cultivars assayed in more homogeneous clusters on the basis of their representative presence in every year and in any of the growing area considered. In Table 1, the cycle length and the genealogy of the cultivars under analysis are reported. The genealogy shows that some cultivars were derived from common progenitors.

\section{Deoxynivalenol analysis}

As regards the determination of DON content, representative grain samples were milled (particle size $\leq 1 \mathrm{~mm}$ ) by 1093 Cyclotec ${ }^{\mathrm{TM}}$ Sample mill (FOSS, Hilleroed, Denmark) and submitted to the mycotoxins analyses by enzyme-linked immuno-sorbent assay (ELISA).

Extraction was performed with aqueous deionised water, according to the Ridascreen ${ }^{\circledR}$ DON method (R-Biopharm AG, Darmstadt, Germany), with limit of detection (LOD) of 18.5 $\mu \mathrm{g} / \mathrm{kg}$. The recovery range declared in the method was $85-110 \%$. Data were acquired as mean of double analysis [coefficient of variation $\leq 10 \%$ ]. The Basic Robotic Immunoassay Operator (BRIO, SEAC, Radim Group, Florence, Italy) was used and the absorbance values were read using Sirio-S Microplate Reader (SEAC, Radim Group). The RIDA ${ }^{\circledR}$ Soft Win software (RBiopharm AG) was employed for quantitation of DON in samples. Distilled water was obtained from Water Purification System Zeener Power I (Human Corporation, Seoul, Korea). The ELISA method employed for the assessment of DON concentration in durum wheat samples had already been submitted to a validation study by comparison with HPLC analysis, within the research project MICOCER (Brera et al., 2009).

\section{Meteorological data}

Data on temperature $\left({ }^{\circ} \mathrm{C}\right)$ and rainfall $(\mathrm{mm})$ on April and May (durum wheat anthesis period) were collected from weather stations located nearby the experimental sites during the 7-year period. The weather conditions during anthesis have a large impact on the Fusarium ssp. infection involved in FHB disease in wheat (De

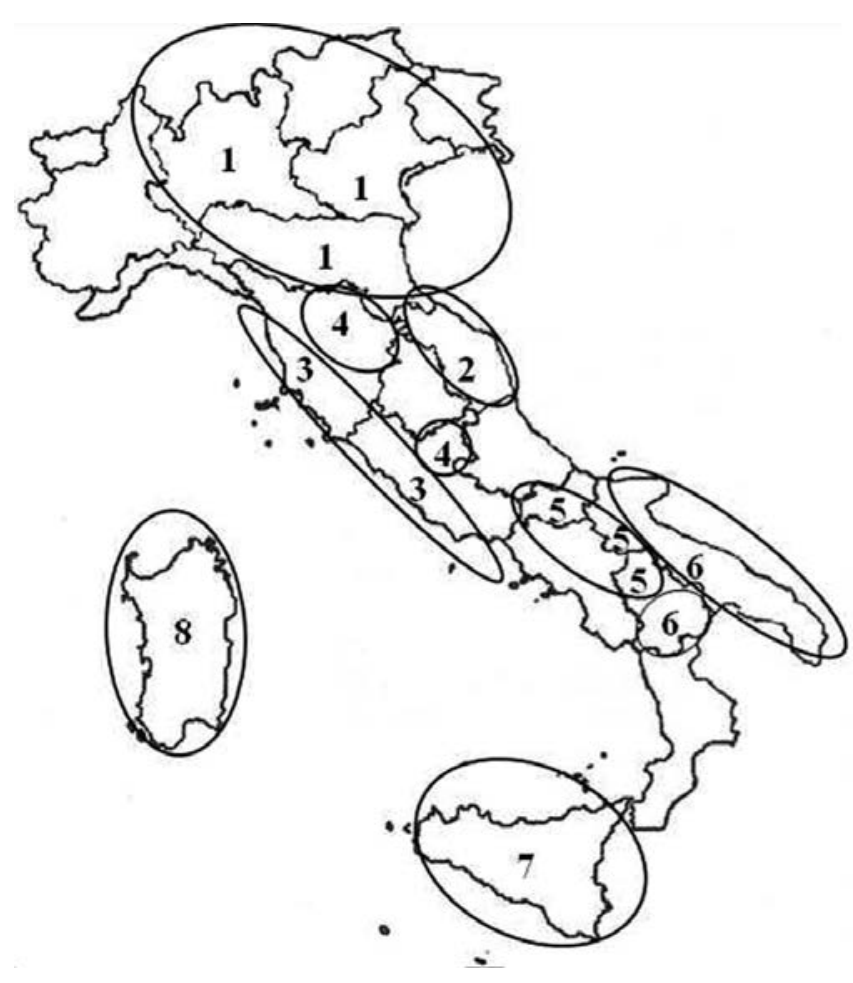

Figure 1. Map of the growing areas of Italy where durum wheat sampling occurred. Numbers are allocated according to the region each area belongs to: 1-North, 2-Centre-East, 3-Centre-West, 4Central Apennines, 5-Southern Apennines, 6-Southern Adriatic Ionian coast, 7-Sicily, and 8-Sardinia. 
Wolf et al., 2003; Xu, 2003; Fedak et al., 2007; Covarelli et al., 2015; Kelly et al., 2015). Climatic conditions consistently affect composition of Fusarium species causing FHB in wheat, especially during wheat anthesis, and together with other factors, such as the lack of crop rotation and the use of mineral fertilisers and pesticides, as it is a practice in conventional systems, heavily influence the FHB occurrence (Bernhoft et al., 2012). The impact of FHB can be limited by adopting measures apt to reduce the inoculum and prevent its dispersal, such as cultural, biological, and chemical control and use of resistant varieties (Magan et al., 2002; Czaban et al., 2015).

\section{Statistical analysis}

In order to assess the distribution of data concerning the DON concentration (c) in samples, descriptive statistics [e.g., mean, standard deviation (SD), range (minimum-maximum) DON concentration, median, $75^{\text {th }}$ percentile and $95^{\text {th }}$ percentile] were obtained. The values of DON concentration (c) in samples on wet basis were expressed as mean of duplicate analyses (coefficient of variation $\leq 10 \%$ ). As to results below LOD, half detection limits $(9.25 \mu \mathrm{g} / \mathrm{kg})$ were used in the statistical tests.

EC Regulation No. 1881/2006 and EC Regulation No. $1126 / 2007$ (European Commission, 2006a, 2007) lay out the maximum limit of $1750 \mu \mathrm{g} / \mathrm{kg}$ for DON in unprocessed durum wheat. The values of DON concentration close to $1750 \mu \mathrm{g} / \mathrm{kg}$, corrected for recovery, were assessed by a discriminating value of 1340 $\mu \mathrm{g} / \mathrm{kg}$ obtained by applying the Horwitz formula for ELISA methods of analysis for expanded measurement of uncertainty as twice of the relative standard deviation (Brera, 2011). However, the use of the aforesaid discriminant value of $1340 \mu \mathrm{g} / \mathrm{kg}$ should not be understood as an evaluation of sample compliance because the method of analysis employed is not suitable to this purpose.

The influence of genotype (CV), growing area (GA), year (Y) and the two-way interaction $\mathrm{CV} \times \mathrm{GA}$ on DON contamination was tested using the powerful statistical technique of generalised linear models (GLZ). The mean response changed as a function of the explanatory variables (CV, GA and Y), and it depended on a linear predictor through a non-linear canonical link function and a Poisson probability distribution. The statistical model was:

$\log (\mathrm{DON})=\beta_{0}+\beta_{1} \tau_{\mathrm{i}}+\beta_{2} \delta_{\mathrm{j}}+\beta_{3} \gamma_{\mathrm{k}}+\beta_{4} \tau_{\mathrm{i}} \cdot \delta_{\mathrm{j}}+\mathrm{e}_{\mathrm{ijk}}$

where $\beta_{0}=$ mean effect common to all observations; $\beta_{1,2,3,4}=$ unknown regression parameters; $\tau_{\mathrm{i}}=$ cultivar $(\mathrm{CV}) ; \mathrm{i}=1, \ldots$ , $16 ; \delta_{\mathrm{j}}=$ growing area $(\mathrm{GA}) ; \mathrm{j}=1, \ldots, 8 ; \gamma_{\mathrm{k}}=$ year $(\mathrm{Y}) ; \mathrm{k}=2012, \ldots$ ,2014; $\mathrm{e}_{\mathrm{ijk}}=$ error term.

The goodness of fit for the GLZ model could be based on the deviance statistics, approximated by a chi-square distribution. We used the log-likelihood value to measure the goodness of fit of the regression models.

\section{Results}

Meteorological data were quite different among the areas during the 7-year period and the major differences were due to spring rainfalls. Regarding areas, a rainfall increase from Southern to Northern regions, and from coastal to inland areas was observed. The Northern area (area 1) was quite favourable for Fusarium spp. infection, as the years under investigation were characterised by rainy springs. No appreciable differences in temperature were observed among areas with the exception of Southern Apennines (area 5), where the lowest mean temperatures were recorded.

\section{Dataset A (1403 durum wheat samples collected in the 3-year period 2012-2014)}

The occurrence of DON was observed in $67 \%$ of the assayed durum wheat samples reporting low values of contamination. The distribution was highly asymmetric: the average concentration on the dataset was $251 \mu \mathrm{g} / \mathrm{kg}$; whereas the median value was 37 $\mu \mathrm{g} / \mathrm{kg} .95 \%$ of samples reported a concentration below $1284 \mu \mathrm{g} / \mathrm{kg}$. Only $4.8 \%$ of total samples exceeded the value of $1750 \mu \mathrm{g} / \mathrm{kg}$.

The descriptive statistics of DON content in the durum wheat

Table 1. List of analysed cultivars in the 3-year period (dataset A) and in the 7-year period (dataset B).

\begin{tabular}{|c|c|c|c|c|}
\hline CV & Cycle length & Genealogy & Dataset A & Dataset B \\
\hline Anco Marzio & $\mathrm{ME}$ & Stot//Altar84/ALD & $\mathrm{X}$ & $\mathrm{X}$ \\
\hline Claudio & M & Sel.Cimmyt35/Durango//IS193B/Grazia & $\mathrm{X}$ & $\mathrm{X}$ \\
\hline Core & $\mathrm{E}$ & Platani/Gianni & $\mathrm{x}$ & \\
\hline Duilio & $\mathrm{E}$ & Cappelli//Anhinga/Flamingo & $\mathrm{X}$ & $\mathrm{X}$ \\
\hline Dylan & ML & Neodur/Ulisse & $\mathrm{X}$ & \\
\hline Iride & $\mathrm{E}$ & Altar84/Ionio & $\mathrm{X}$ & $\mathrm{X}$ \\
\hline Kanakis & M & (Unavailable) & $\mathrm{X}$ & \\
\hline Marco Aurelio & M & Orobel//Arcobaleno/Svevo & $\mathrm{X}$ & \\
\hline Massimo Meridio & M & Orobel//Arcobaleno/Svevo & $\mathrm{X}$ & \\
\hline Odisseo & ML & Svevo/led24 & $\mathrm{X}$ & \\
\hline Ramirez & M & (Unavailable) & $\mathrm{X}$ & \\
\hline Saragolla & $\mathrm{E}$ & Iride/Linea PSB0114 & $\mathrm{X}$ & $\mathrm{X}$ \\
\hline Sculptur & M & (Unavailable) & $\mathrm{X}$ & \\
\hline Simeto & ME & Capeiti8/Nalnova & $\mathrm{X}$ & $\mathrm{X}$ \\
\hline Svevo & $\mathrm{E}$ & Linea Cimmyt/Zenit & $\mathrm{X}$ & $\mathrm{X}$ \\
\hline Tirex & $\mathrm{ME}$ & Svevo/Nefer & $\mathrm{X}$ & \\
\hline
\end{tabular}

E, early; M, medium; L, late. For each cultivar the length of cycle until anthesis and the genealogy were reported. 
samples under investigation are shown in Table 2 and reported according to cultivar; whereas Table 3 shows data according to the cultivation area. In the analysed cultivars, mean values ranged between $162 \mu \mathrm{g} / \mathrm{kg}$ for Odisseo and $402 \mu \mathrm{g} / \mathrm{kg}$ for Simeto. The $95^{\text {th }}$ percentile showed values closed to the value of $1750 \mu \mathrm{g} / \mathrm{kg}$ in the cultivars Massimo Meridio (2730 $\mu \mathrm{g} / \mathrm{kg}$ ), Marco Aurelio (2214 $\mu \mathrm{g} / \mathrm{kg})$, Duilio (2129 $\mu \mathrm{g} / \mathrm{kg})$, Simeto (1714 $\mu \mathrm{g} / \mathrm{kg})$, Core (1536 $\mu \mathrm{g} / \mathrm{kg})$ and Anco Marzio $(1321 \mu \mathrm{g} / \mathrm{kg})$ corrected for recovery. The cultivars Simeto, Claudio and Duilio showed the highest detected values $(14452,10704$ and $8496 \mu \mathrm{g} / \mathrm{kg}$, respectively).

The incidence rate, intended as percentage of positive samples (c $\geq$ LOD) for DON, out of the total number of assayed samples,

Table 2. Descriptive statistics of deoxynivalenol occurrence contamination (1403 samples concerning 2012-2014 years) according to cultivar: mean, standard deviation, range, median, $75^{\text {th }}$ percentile, $95^{\text {th }}$ percentile.

\begin{tabular}{|c|c|c|c|c|c|c|c|c|}
\hline CV & & & Whole da & set & & & $\begin{array}{r}\text { Positiv } \\
(c \geq\end{array}$ & $\begin{array}{l}\text { e samples } \\
\text { LOD) }\end{array}$ \\
\hline & Mean ( $\mu g / k g)$ & SD ( $\mu g / k g)$ & Range ( $\mu g / k g)$ & Q2 ( $\mu \mathrm{g} / \mathrm{kg})$ & Q3 ( $\mu g / k g)$ & P95 ( $\mu \mathrm{g} / \mathrm{kg})$ & Samples (\%) & Mean ( $\mu \mathrm{g} / \mathrm{kg})$ \\
\hline Anco Marzio & 238 & 561 & $<$ LOD-3042 & 39 & 173 & 1321 & 72 & 326 \\
\hline Claudio & 293 & 1123 & $<$ LOD-10704 & 37 & 137 & 1118 & 70 & 413 \\
\hline Core & 228 & 643 & $<$ LOD-4560 & 34 & 124 & 1536 & 61 & 371 \\
\hline Duilio & 355 & 1057 & $<$ LOD-8496 & 36 & 227 & 2129 & 65 & 541 \\
\hline Dylan & 233 & 540 & $<$ LOD-2900 & 34 & 146 & 1272 & 67 & 345 \\
\hline Iride & 175 & 537 & $<$ LOD-4713 & 36 & 97 & 769 & 65 & 264 \\
\hline Kanakis & 249 & 601 & $<$ LOD-3275 & 28 & 173 & 1267 & 63 & 392 \\
\hline Marco Aurelio & 343 & 885 & $<$ LOD-5394 & 51 & 153 & 2214 & 72 & 474 \\
\hline Massimo Meridio & 337 & 890 & $<$ LOD-4757 & 38 & 138 & 2730 & 66 & 505 \\
\hline Odisseo & 162 & 453 & $<$ LOD-3084 & 30 & 80 & 905 & 63 & 251 \\
\hline Ramirez & 179 & 394 & $<$ LOD-2378 & 43 & 129 & 964 & 64 & 276 \\
\hline Saragolla & 183 & 427 & $<$ LOD-2428 & 43 & 107 & 1254 & 66 & 274 \\
\hline Sculptur & 220 & 579 & $<$ LOD-2799 & 36 & 109 & 1299 & 66 & 328 \\
\hline Simeto & 402 & 1522 & $<$ LOD-14452 & 44 & 167 & 1714 & 67 & 598 \\
\hline Svevo & 190 & 454 & $<$ LOD-3190 & 38 & 95 & 1215 & 71 & 264 \\
\hline Tirex & 243 & 554 & $<$ LOD-3817 & 39 & 149 & 1305 & 76 & 318 \\
\hline
\end{tabular}

CV, cultivar; SD, standard deviation; Q2, median; Q3, $75^{\text {th }}$ percentile; P95, 95 th percentile; LOD, limit of detection $(18.5 \mu \mathrm{g} / \mathrm{kg})$. Results minor than the limit of detection were set to 9.25 for the calculation of means $\mathrm{c}=\mathrm{DON}$ concentration $(\mu \mathrm{g} / \mathrm{kg})$. Positive samples: percentage of positive samples and mean.

Table 3. Descriptive statistics of deoxynivalenol occurrence contamination (1403 samples concerning 2012-2014 years) according to cultivation area: mean, standard deviation, range, median, $75^{\text {th }}$ percentile, $95^{\text {th }}$ percentile.

\begin{tabular}{|c|c|c|c|c|c|c|c|c|}
\hline Area & Yean $(\mu g / k g)$ & SD ( $\mu g / k g)$ & \multicolumn{4}{|c|}{ Whole dataset } & \multicolumn{2}{|c|}{$\begin{array}{l}\text { Positive samples } \\
(c \geq L O D)\end{array}$} \\
\hline North & 1016 & 1633 & $<$ LOD-14452 & 401 & 1263 & 3528 & 96 & 1057 \\
\hline Centre-East & 177 & 359 & $<$ LOD-3223 & 53 & 145 & 872 & 78 & 224 \\
\hline Centre-West & 153 & 314 & $<$ LOD-2479 & 71 & 167 & 443 & 84 & 181 \\
\hline Central Apennines & 215 & 466 & $<$ LOD-2770 & 53 & 161 & 1118 & 74 & 286 \\
\hline Southern Apennines & 21 & 29 & $<$ LOD-289 & $<\mathrm{LOD}$ & 21 & 76 & 32 & 47 \\
\hline Southern Adriatic Ionian coast & 48 & 58 & $<$ LOD-375 & 27 & 56 & 137 & 73 & 62 \\
\hline Sicily & 24 & 26 & $<$ LOD-196 & $<\mathrm{LOD}$ & 27 & 76 & 45 & 43 \\
\hline Sardinia & 37 & 35 & $<$ LOD-163 & 28 & 52 & 112 & 58 & 57 \\
\hline
\end{tabular}

SD, standard deviation; Q2, median; Q3, $75^{\text {th }}$ percentile; P95, 95 th percentile; LOD, limit of detection ( $\left.18.5 \mu \mathrm{g} / \mathrm{kg}\right)$. Results minor than the limit of detection were set to 9.25 for the calculation of means; c=DON concentration $(\mu \mathrm{g} / \mathrm{kg})$. Positive samples: percentage of positive samples and mean.

Table 4. Descriptive statistics of deoxynivalenol occurrence contamination (1403 samples concerning 2012-2014 years) according to growing year: mean, standard deviation, range, median, $75^{\text {th }}$ percentile, $95^{\text {th }}$ percentile.

\begin{tabular}{|c|c|c|c|c|c|c|c|c|}
\hline \multirow[t]{2}{*}{ Year } & \multicolumn{6}{|c|}{ Whole dataset } & \multirow{2}{*}{\multicolumn{2}{|c|}{$\begin{array}{l}\text { Positive samples } \\
\quad(c \geq L O D) \\
\text { oles (\%) Mean }(\mu \mathrm{g} / \mathrm{kg})\end{array}$}} \\
\hline & Mean ( $\mu g / k g)$ & SD $(\mu g / k g)$ & Range ( $\mu \mathrm{g} / \mathrm{kg})$ & Q2 ( $\mu g / k g)$ & Q3 ( $\mu \mathrm{g} / \mathrm{kg})$ & P95 ( $\mu \mathrm{g} / \mathrm{kg})$ & & \\
\hline 2012 & 150 & 374 & $<$ LOD-2799 & 29 & 91 & 837 & 64 & 230 \\
\hline 2013 & 402 & 1201 & $<$ LOD-14452 & 45 & 181 & 2484 & 70 & 567 \\
\hline 2014 & 204 & 426 & $<$ LOD-2770 & 40 & 138 & 1181 & 68 & 296 \\
\hline
\end{tabular}

SD, standard deviation; Q2, median; Q3, $75^{\text {th }}$ percentile; P95, 95 th percentile; LOD, limit of detection (18.5 $\mu \mathrm{g} / \mathrm{kg}$ ). Results less than the limit of detection were set to 9.25 for the calculation of means; c=DON concentration $(\mu \mathrm{g} / \mathrm{kg})$. Positive samples: percentage of positive samples and mean. 
was $67 \%$ in the 1403 durum wheat samples with an average concentration of DON equal to $369 \mu \mathrm{g} / \mathrm{kg}$. The incidence of DON varied depending on the cultivar, area and year. Within each cultivar, more than $60 \%$ of samples resulted positive. In particular, samples belonging to the cultivar Tirex, Marco Aurelio, Anco Marzio, Svevo and Claudio resulted the most contaminated, although the highest mean values ( $>500 \mu \mathrm{g} / \mathrm{kg}$ ) were recorded by Simeto, Duilio and Massimo Meridio (Table 2). As shown in Table 3, DON levels were heavily influenced by the geographical growing area: Northern Italy showed, for instance, considerable amount of DON with a mean value $(1016 \mu \mathrm{g} / \mathrm{kg})$ far higher than those detected in the other areas. Furthermore, the negligible concentrations of this mycotoxin were also confirmed both in Southern Italy, Sicily and Sardinia. The lowest incidence and means of DON were recorded in Southern Apennines, Sicily and Sardinia, where means of positive samples were lower than $60 \mu \mathrm{g} / \mathrm{kg}$. In particular, in Southern Apennines only $32 \%$ of samples exceeded the detection limit with a very low mean value of DON $(47 \mu \mathrm{g} / \mathrm{kg})$. On the other hand, the highest values were obtained for samples of grains grown in Northern Italy, where DON contamination affected $96 \%$ of samples, with an average concentration of $1057 \mu \mathrm{g} / \mathrm{kg}$. As regards the three years assayed, namely 2012-2014 (Table 4), the highest DON levels were observed in 2013: the mean value was $402 \mu \mathrm{g} / \mathrm{kg}$, the $95^{\text {th }}$ percentile far exceeded the value of $1750 \mu \mathrm{g} / \mathrm{kg}$, and the maximum reached 14452 $\mu \mathrm{g} / \mathrm{kg}$. Over that year, $70 \%$ of samples resulted positive to DON. In 2012, DON was present in similar percentages of positivity ( $64 \%$ of samples), but with an average level of only $150 \mu \mathrm{g} / \mathrm{kg}$. DON values during 2014 were comparable with those of 2012.

The GLZ analysis showed that all single factors and the interaction between cultivar and area were highly significant $(\mathrm{P}<0.0001)$, although a marked difference in $\chi^{2}$ values among factors was highlighted (Table 5). The growing area was the main contributing factor to deoxynivalenol content $\left(\chi^{2}=114540\right)$, followed by year $\left(\chi^{2}=5504\right)$, cultivar $\left(\chi^{2}=1239\right)$ and the two-way $(\mathrm{CV} \times \mathrm{GA})$ interaction $\left(\chi^{2}=281\right)$.

As the other interactions in the complete model were not significant, a reduced model was used. The model took into consideration the only interaction which was significant $(\mathrm{CV} \times \mathrm{GA})$. Interactions between the remaining factors are not shown because not significant. Moreover, the behaviour of the 16 cultivars assayed in the three-year period was highlighted by applying the GLZ analysis of data concerning the DON content.

The GLZ analysis allows to distinguish and order the varieties under analysis on the basis of each factor (i.e., area, year and cultivar), as well as of the interaction $\mathrm{CV} \times \mathrm{GA}$. Hence, the variety classification obtained upon ranking does not straight match the classification deriving from the means (Table 6). In order to assess any change of cultivar ranking due to the different geographical position of the cropping areas, the data regarding the three areas with a major presence of DON (i.e., North, Centre-East and Central-Apennines) were selected (Table 7). Despite some differences among the growing areas, the results confirmed the general trend. In fact, the cultivars Simeto and Duilio resulted highly susceptible to DON accumulation in kernels in all areas assayed, whereas Odisseo appeared the most resistant. The Iride CV behaviour was greatly influenced by the growing areas: high values of DON content were observed in East-Central Italy, Central Apennines and Northern Italy (mean $=303 \mu \mathrm{g} / \mathrm{kg}, 95^{\text {th }}$ percentile $=1268 \mu \mathrm{g} / \mathrm{kg}$ ), whereas lower values were obtained in the remaining areas of Italy (mean $=43 \mu \mathrm{g} / \mathrm{kg}, 95^{\text {th }}$ percentile $=132$ $\mu \mathrm{g} / \mathrm{kg}$ ). It could explain the different position in cultivar ranking related to the measured DON content.

\section{Dataset B (2080 durum wheat samples collected in two periods, 2006-2008 and 2011-2014)}

The GLZ analysis of the second dataset, comprising seven durum wheat cultivars over a 7-year period, was useful to confirm both the general trend of cultivar behaviour towards the DON contamination and the influence of several environmental factors. DON content in kernels was mainly influenced by the cropping area $\left(\chi^{2}=526328 ; \mathrm{P}<0.0001\right)$, but also by the year $\left(\chi^{2}=21966\right.$; $\mathrm{P}<0.0001)$, cultivar $\left(\chi^{2}=11545 ; \mathrm{P}<0.0001\right)$ and the two-way interaction $\mathrm{CV}^{*}$ area $\left(\chi^{2}=5168 ; \mathrm{P}<0.0001\right)$. An increased susceptibility to higher concentration of DON was highlighted for the cultivars Simeto and Duilio, whereas Saragolla and Svevo showed a trend of lower contamination levels (Table 7).

\section{Discussion}

Genotype-by-environment interactions and the complex nature of FHB are among the most important aspects to be considered for breeding challenges (Bai and Shaner, 1994; Buerstmayr et al., 2013). However, nowadays no full indication exists about the wheat cultivars with a high level of resistance to Fusarium spp. that might limit yield loss and mycotoxin accumulation. As the utilisation of FHB-resistant cultivars could be an effective approach for the protection of wheat against FHB disease, new sources of FHB resistance have increasingly been in high demand among wheat breeders.

Resistant cultivars can develop active defense reactions during infection and thus determine a lower accumulation of DON in the tissues of infected spikes of resistant wheat cultivars (Kang and Buchenauer, 2000). Wheat resistance to FHB is affected by the relationship between symptom intensity and toxin production, and this inheritance has a quantitative and polygenic nature.

It is known that DON plays a key role as a powerful virulence factor during fungal pathogenesis; resistance to this mycotoxin is therefore an important component of resistance against FHB. Resistance aspects determine the severity of FHB (I-IV resistance), however, other mechanisms may influence DON content in kernels, which limit the trichothecene accumulation in cereals, including the transformation of the mycotoxin that is named type $\mathrm{V}-1$ (Boutigny et al., 2008). Several studies are available in literature about the mechanisms of resistance to DON which comprise the conversion of DON into less toxic metabolites, such as deoxynivalenol-3-O-glucoside (D3G), with a good correlation between FHB resistance and DON conversion rate, expressed as $[\mathrm{D} 3 \mathrm{G}] /[\mathrm{DON}]$ ratio in durum wheat (Audenaert et al., 2013; Berthiller et al., 2005; Cirlini et al., 2014; Kluger et al., 2015; Lemmens et al., 2005) and DON-glutathione (DON-GSH) (Krska

Table 5. $\chi^{2}$ values and significance levels from generalised linear models regression for deoxynivalenol occurrence (1403 samples concerning 2012-2014 years).

\begin{tabular}{lcc}
\hline Factor & $\chi^{2}$ & $\operatorname{Pr}>\chi^{2}$ \\
$\mathrm{CV}$ & 1239 & $<0.0001$ \\
\hline $\mathrm{GA}$ & 114540 & $<0.0001$ \\
Year & 5504 & $<0.0001$ \\
\hline $\mathrm{CV} * \mathrm{GA}$ & 281 & $<0.0001$
\end{tabular}

$\mathrm{CV}$, cultivar; $\mathrm{GA}$, growing area. 
et al., 2014; Stanic et al., 2014). D3G is also defined as masked form of DON. This compound has a lower acute toxicity compared to his parent mycotoxin particularly in the binding to the ribosome and its intestinal toxicity (Pierron et al., 2016). However, it can be hydrolysed by several intestinal bacteria releasing free DON and this fact is of great toxicological concern (Berthiller et al., 2011).
In this work, the evaluation of DON content in durum wheat samples was carried out by Ridascreen ${ }^{\circledR} \mathrm{DON}$ which employs an antibody showing a declared cross-reactions with other DONconjugated compounds (e.g., 3-acetyl-deoxynivalenol and 15acetyl-deoxynivalenol). Moreover, besides these interfering compounds, a marked cross-reaction between antibody and D3G

Table 6. Descriptive statistics of the cultivars assayed in 3-year period (2012-2014, dataset A) and in 7-year period (2006-2008 and 2011-2014, dataset B) of deoxynivalenol occurrence mean concentration $(\mu \mathrm{g} / \mathrm{kg})$ in each cultivation area.

\begin{tabular}{|c|c|c|c|c|c|c|c|c|c|}
\hline & & North & $\begin{array}{l}\text { Centre } \\
\text { East }\end{array}$ & $\begin{array}{l}\text { Centre } \\
\text { West }\end{array}$ & $\begin{array}{c}\text { Central } \\
\text { Apennines }\end{array}$ & $\begin{array}{l}\text { Southern } \\
\text { Apennines }\end{array}$ & $\begin{array}{l}\text { Southern } \\
\text { Adriatic Ionian coast }\end{array}$ & Sicily & Sardinia \\
\hline Dataset A & $\begin{array}{l}\text { Anco Marzio } \\
\text { Claudio } \\
\text { Core } \\
\text { Duilio } \\
\text { Dylan } \\
\text { Iride } \\
\text { Kanakis } \\
\text { Marco Aurelio } \\
\text { Massimo Meridio } \\
\text { Odisseo } \\
\text { Ramirez } \\
\text { Saragolla } \\
\text { Sculptur } \\
\text { Simeto } \\
\text { Svevo } \\
\text { Tirex }\end{array}$ & $\begin{array}{c}912 \\
1618 \\
806 \\
1490 \\
618 \\
781 \\
904 \\
1281 \\
1226 \\
584 \\
591 \\
828 \\
863 \\
2198 \\
777 \\
804\end{array}$ & $\begin{array}{l}164 \\
152 \\
236 \\
290 \\
143 \\
159 \\
228 \\
202 \\
250 \\
89 \\
203 \\
155 \\
124 \\
412 \\
115 \\
163\end{array}$ & $\begin{array}{c}144 \\
61 \\
72 \\
171 \\
577 \\
108 \\
67 \\
104 \\
102 \\
71 \\
122 \\
76 \\
89 \\
192 \\
96 \\
310\end{array}$ & $\begin{array}{l}195 \\
173 \\
157 \\
377 \\
129 \\
251 \\
207 \\
335 \\
353 \\
150 \\
162 \\
165 \\
123 \\
452 \\
150 \\
131\end{array}$ & $\begin{aligned} & 30 \\
&<<O D \\
& 22 \\
& 29 \\
&< \text { LOD } \\
& 24 \\
&< \text { LOD } \\
&<\text { LOD } \\
&<\text { LOD } \\
&<\text { LOD } \\
&<\text { LOD } \\
& 23 \\
&<\text { LOD } \\
& 36 \\
&<\text { LOD } \\
& 26\end{aligned}$ & $\begin{array}{l}29 \\
42 \\
42 \\
38 \\
56 \\
37 \\
25 \\
39 \\
30 \\
38 \\
25 \\
59 \\
28 \\
59 \\
47 \\
48\end{array}$ & $\begin{aligned} & 23 \\
& 28 \\
& 19 \\
&<\text { LOD } \\
& 23 \\
&<\text { LOD } \\
& 25 \\
& 29 \\
& 22 \\
& 21 \\
& 30 \\
& 28 \\
& 22 \\
& 25 \\
& 30 \\
& 40\end{aligned}$ & $\begin{array}{l}49 \\
55 \\
27 \\
42 \\
22 \\
55 \\
34 \\
50 \\
22 \\
22 \\
36 \\
33 \\
34 \\
48 \\
33 \\
24\end{array}$ \\
\hline Dataset B & $\begin{array}{l}\text { Anco Marzio } \\
\text { Claudio } \\
\text { Duilio } \\
\text { Iride } \\
\text { Saragolla } \\
\text { Simeto } \\
\text { Svevo }\end{array}$ & $\begin{array}{c}619 \\
846 \\
992 \\
658 \\
564 \\
1464 \\
583\end{array}$ & $\begin{array}{c}188 \\
338 \\
341 \\
239 \\
167 \\
428 \\
70\end{array}$ & $\begin{array}{c}130 \\
102 \\
178 \\
135 \\
92 \\
211 \\
78\end{array}$ & $\begin{array}{l}152 \\
106 \\
134 \\
126 \\
113 \\
222 \\
111\end{array}$ & $\begin{array}{c}35 \\
23 \\
25 \\
22 \\
30 \\
19 \\
<\text { LOD }\end{array}$ & $\begin{array}{l}30 \\
26 \\
41 \\
33 \\
53 \\
34 \\
26\end{array}$ & $\begin{array}{l}28 \\
24 \\
20 \\
21 \\
40 \\
27 \\
30\end{array}$ & $\begin{array}{l}81 \\
38 \\
44 \\
44 \\
47 \\
50 \\
35\end{array}$ \\
\hline
\end{tabular}

LOD, limit of detection $(18.5 \mu \mathrm{g} / \mathrm{kg})$. Results less than the limit of detection were set to 9.25 for the calculation of means. Deoxynivalenol mean values $(\mu \mathrm{g} / \mathrm{kg})$ in the cultivation areas.

Table 7. Generalised linear models analysis: detailed ranking of the cultivars assayed in 3-year period (2012-2014, dataset A) and in 7year period (2006-2008 and 2011-2014, dataset B) in three cultivation areas from the minimum (up) to the maximum (bottom) deoxynivalenol occurrence mean content $(\mu \mathrm{g} / \mathrm{kg})$.

\begin{tabular}{|c|c|c|c|c|}
\hline & & & & \\
\hline & Total areas & North & Centre-East & Central Apennines \\
\hline Dataset A & Iride $^{\mathrm{a}}$ & Odisse $^{\mathrm{a}}$ & Odisse $^{\mathrm{a}}$ & Sculptura \\
\hline & Odisse $^{a, b}$ & Ramireza $^{\mathrm{a}}$ & Sculptur ${ }^{b}$ & Tirex ${ }^{a}$ \\
\hline & Dylan b,c & Dylanb & Svevo $^{c}$ & Dylan $^{\mathrm{a}}$ \\
\hline & Ramirez $^{c}$ & Svevo $^{c}$ & Dylan $^{\mathrm{d}}$ & Svevo $^{\mathrm{b}}$ \\
\hline & Saragolla $^{\mathrm{d}}$ & Iride $^{\mathrm{d}}$ & Anco Marzio ${ }^{\mathrm{e}}$ & Odisse $^{\mathrm{b}}$ \\
\hline & Svevo ${ }^{\mathrm{e}}$ & Tirex ${ }^{e}$ & Tirex & Core $^{b, c}$ \\
\hline & Tirex $^{\mathrm{e}}$ & Core $^{f}$ & Claudio ${ }^{f}$ & Ramirez $^{\mathrm{c}}$ \\
\hline & Core $^{f}$ & Saragolla ${ }^{g}$ & Marco Aureliog & Saragolla ${ }^{c}$ \\
\hline & Anco Marziog & Sculptur ${ }^{\mathrm{h}}$ & Ramirez ${ }^{g}$ & Anco Marzio ${ }^{d}$ \\
\hline & Sculptur h & Kanakis ${ }^{\mathrm{i}}$ & Saragollah & Kanakis $^{\mathrm{d}}$ \\
\hline & Kanakis $^{\mathrm{h}}$ & Anco Marzio $^{\mathrm{i}}$ & Kanakis ${ }^{i}$ & Claudio ${ }^{\mathrm{e}}$ \\
\hline & Marco Aurelio ${ }^{\mathrm{i}}$ & Massimo Meridioj & Iridej & Iride $^{\mathrm{f}}$ \\
\hline & Massimo Meridio ${ }^{\mathrm{i}}$ & Marco Aureliok & Core $^{k}$ & Marco Aureliog \\
\hline & Duilioj & Duiliol & Massimo Meridio $^{k}$ & Massimo Meridio ${ }^{\mathrm{h}}$ \\
\hline & Claudiok $^{k}$ & Claudio $^{\mathrm{m}}$ & Duilio ${ }^{1}$ & Duilio $^{\mathrm{i}}$ \\
\hline & Simeto $^{1}$ & Simeto ${ }^{\mathrm{n}}$ & Simeto $^{m}$ & Simeto $^{j}$ \\
\hline Dataset B & Saragolla ${ }^{a}$ & Svevo $^{\mathrm{a}}$ & Svevo $^{\mathrm{a}}$ & Svevo $^{\mathrm{a}}$ \\
\hline & Svevo $^{a}$ & Saragolla $^{a}$ & Saragollab & Saragollab \\
\hline & Anco Marzio ${ }^{b}$ & Anco Marzio ${ }^{b}$ & Anco Marzioc ${ }^{c}$ & Claudioc \\
\hline & Iride $^{c}$ & Iride $^{\mathrm{c}}$ & Duilio $^{d}$ & Anco Marzio ${ }^{d}$ \\
\hline & Claudio $^{d}$ & Claudio $^{\mathrm{d}}$ & Claudio $^{\mathrm{d}}$ & Iride $^{\mathrm{e}}$ \\
\hline & Duilio $^{\mathrm{e}}$ & Duilio $^{\mathrm{e}}$ & Simeto ${ }^{\mathrm{e}}$ & Duilio $^{f}$ \\
\hline & Simeto ${ }^{f}$ & Simeto $^{\mathrm{f}}$ & Iride & Simetog \\
\hline
\end{tabular}

${ }^{\mathrm{a}-\mathrm{n}}$ Cultivars within columns of each dataset followed by different letters are significantly different at $\mathrm{P}<0.05$. 
was relieved (Berthiller et al., 2013; Zachariasova et al., 2008).

The DON concentration detected in samples is to be intended as the whole form of DON recognised by the antibody employed. The quite similar trend of percentage of samples positive for DON (from 61 to $76 \%$ ) within the 16 cultivars against different values of 95 $5^{\text {th }}$ percentile (from 769 to $2730 \mu \mathrm{g} / \mathrm{kg}$ ) suggested a different response to accumulate the mycotoxin in the host kernels. Indeed, the different behaviour towards DON accumulation in kernels allowed ranking cultivars on the basis of significant differences about the mycotoxin content. To this aim, the choice to select the cultivation areas with greater levels of contamination allowed to better identify the response of each cultivar to the fungal aggressiveness in terms of DON production. The classification of cultivars within the total areas group did not differ a lot from each single area of cultivation with a major risk of contamination. The susceptibility of cultivars, emerged within the tested area, has substantially a similar trend than in the areas reported in Table 7. The Odisseo CV showed a minor tendency to the DON accumulation in kernels all over the cultivation areas assayed. Moreover, in case of higher exposition of plants to DON contamination, such as in the North, or more in general in the case of the assayed total areas, the cultivars Iride, Dylan, Ramirez and Svevo showed a fairly good resistance to the mycotoxin occurrence. Our results also hinted that the length of the wheat crop cycle does not affect the levels of DON contamination detected in kernels. This outcome further highlights the importance of the cultivar own capability to actively counteract the fungal aggressiveness. The slight differences in the position of each of the 16 cultivars within the area also highlighted the importance of environmental conditions on their behaviour with regard to DON content in kernels.

In case of FHB outbreak on wheat plants, due to the landing of fungi, such as $F$. graminearum and $F$. culmorum, the growth of mycelia and the ability to produce mycotoxins are greatly influenced by many factors and interactions thereof, such as the aggressiveness of the fungal species, the host susceptibility and the cultivar resistance level. The latter are also strongly related to plant exposure to FHB risk and mycotoxin accumulation due to a several environmental factors involving key parameters (e.g., temperature, relative humidity, rainfall, previous crop and crop residue management) (Cromery et al., 2002; Lori et al., 2009; Wegulo, 2012). The area was the main contributing factor to the DON occurrence, as it takes into account both the high climate and geographic variability of Italy.

These data also match results obtained in a previous study on the occurrence of trichothecenes in organic and conventional durum wheat in Italy, where the major influence of the area as a single factor and its interaction with the year was showed (Quaranta et al., 2010). It also emerged that the importance of the effect of the growing year should not be overlooked as shown in previous works (Aureli et al., 2015; Camerini et al., 2015). As to the importance of the environment, the higher mean and maximum values of DON content detected in 2013 should be reasonably connected with the high amount of rainfall occurring in May in Northern and Central Italy.

This work provides information about the behaviour of several durum wheat cultivars, widely grown in Italy, in function of the level of deoxynivalenol contamination in whole milled kernels. It hence contributes to bringing new knowledge to a field where there is still a limited availability of information, that is, resistance sources for durum wheat against Fusarium Head Blight, with emphasis on plant capability to contrast the production and/or accumulation of mycotoxins in kernels. The results obtained by the statistical analysis (GLZ), especially for areas with a major DON contamination, highlight a general trend ranking of cultivars based on their sensitivity to DON accumulation in raw matter.

Among the cultivars investigated in this work, Odisseo CV generally showed a minor sensitivity, whereas a higher susceptibility to DON contamination was revealed for Simeto and Duilio. The analysis of all cultivars allowed highlighting that the length of wheat crop cycle does not affect the levels of DON contamination detected in kernels.

The major influence of the area factor and its two-way interaction with the cultivar factor was shown. Because of the role played by the area factor, slight differences along the cultivar ranking for each area assayed were also outlined. This result confirms that it represents one of the most important factors together with the year factor able to heavily influence the DON accumulation occurring in durum wheat grain in Italy (Quaranta et al., 2010; Aureli et al., 2015). Therefore, in spite of the expanded sowing of this species towards the Northern region of Italy, both the Centre-South and islands areas remain the more suitable regions for growing this type of culture.

\section{Conclusions}

This study is a first attempt of forward-looking approaches to a better understanding of cultivar susceptibility to mycotoxin accumulation in grains. It has clearly emerged the pivotal role of the factor cultivar. However, other factors, such as environment and agronomic practices, have not to be neglected. It is worth highlighting that the obtained information is likely of use for farmers when deciding for the most suitable cultivar, and of interest for breeding programmes in durum wheat.

\section{References}

Antonissen G, Martel A, Pasmans F, Ducatelle R, Verbrugghe E, Vandenbroucke V, Li S, Haesebrouck F, Van Immerseel F, Croubels S, 2014. The impact of Fusarium mycotoxins on human and animal host susceptibility to infectious diseases. Toxins 6:430-52.

Arunachalam C, Doohan FM, 2013. Trichothecene toxicity in eukaryotes: Cellular and molecular mechanisms in plants and animals. Toxicol. Lett. 217:149-58.

Audenaert K, Vanheule A, Höfte M, Haesaert G, 2013. Deoxynivalenol: a major player in the multifaceted response of Fusarium to its environment. Toxins 1:19-6.

Aureli G, Amoriello T, Belocchi A, D'Egidio MG, Fornara M, Melloni S, Quaranta F, 2015. Preliminary survey on the cooccurrence of DON and T2+HT2 toxins in durum wheat in Italy. Cereal Res. Commun. 43:481-91.

Bai G, Shaner G, 1994. Scab of wheat: prospects for control. Plant Dis. 760:766-78.

Bernhoft A, Torp M, Clasen PE, Løes AK, Kristoffersen AB, 2012. Influence of agronomic and climatic factors on Fusarium infestation and mycotoxin contamination of cereals in Norway. Food Addit. Contam. 29:1129-40.

Berthiller F, Crews C, Dall'Asta C, De Saeger S, Haesaert G, Karlovsky P, Oswald I, Seefelder W, Speijers G, Stroka J, 2013. Masked mycotoxins: A review. Mol. Nutr. Food Res. 57:165-86.

Berthiller F, Dall'Asta C, Schuhmacher R, Lemmens M, Adam G, 
Krska R, 2005. Masked mycotoxins: determination of a deoxynivalenol glucoside in artificially and naturally contaminated wheat by liquid chromatography-tandem mass spectrometry. J. Agric. Food Chem. 53:3421-5.

Berthiller F, Krska R, Domig KJ, Kneifel W, Juge N, Schuhmacher R, Adam G, 2011. Hydrolytic fate of deoxynivalenol-3-glucoside during digestion. Toxicol. Lett. 206:264-7.

Bottalico A, Perrone G, 2002. Toxigenic Fusarium species and mycotoxins associated with head blight in small-grain cereals in Europe. Eur. J. Plant Pathol. 108:611-24.

Boutigny AL, Forget FR, Barreau C, 2008. Natural mechanisms for cereal resistance to the accumulation of Fusarium trichothecenes. Eur. Plant Pathol. 121:411-23.

Brera C, 2011. Linea guida sulla interpretazione dei regolamenti comunitari nella valutazione della conformità del Deossinivalenolo (DON) nel frumento e prodotti derivati. ITALMOPA, Rome, Italy.

Brera C, Debegnach F, De Santis B, Pannunzi E, Berdini C, Prantera E, Miraglia M, 2009. Validazione di metodi immunoenzimatici per la determinazione delle micotossine in campioni di cereali. I Georgofili Quaderni 2008-IV:3-45.

Buerstmayr H, Ban T, Anderson JA, 2009. QTL mapping and marker-assisted selection for Fusarium head blight resistance in wheat: a review. Plant Breed. 128:1-26.

Buerstmayr M, Abdallah A, Steiner B, Buerstmayr H, 2013. Genetic mapping of QTL for resistance to Fusarium head blight spread (type 2 resistance) in a Triticum dicoccoides $\mathrm{x}$ Triticum durum backcross-derived population. Theor. Appl. Genet. 126:2825-34.

Buerstmayr M, Huber K, Heckmann J, Steiner B, Nelson JC, Buerstmayr H, 2012. Mapping of QTL for Fusarium head blight resistance and morphological and developmental traits in three backcross populations derived from Triticum dicoccum x Triticum durum. Theor. Appl. Genet. 125:1751-65.

Camerini M, Amoriello T, Aureli G, Belocchi A, Fornara M, Melloni S, Quaranta F, 2015. Deoxynivalenol content in Italian organic durum wheat: results of a six-year survey. Cereal Res. Commun. 44:122-30.

Cirlini M, Generotti S, Dall'Erta A, Lancioni P, Ferrazzano G, Massi A, Galaverna G, Dall'Asta C, 2014. Durum wheat (Triticum Durum Desf.) lines show different abilities to form masked mycotoxins under greenhouse conditions. Toxins 81:95-6.

Covarelli L, Beccari G, Prodi A, Generotti S, Etruschi F, Juan C, Ferrer E, Mañes J, 2015. Fusarium species, chemotype characterisation and trichothecene contamination of durum and soft wheat in an area of central Italy. J. Sci. Food Agric. 95:541-51.

Cromery MG, Shorter SC, Lauren DR, Sinclar KI, 2002. Cultivar and crop management influences on fusarium head blight and mycotoxins in spring wheat (Triticum aestivum) in New Zeland. New Zeland J. Crop Horticult. Sci. 30:235-47.

Czaban J, Wróblewska B, Sułek A, Mikos M, Boguszewska E, Podolska G, Nieróbca A, 2015. Colonisation of winter wheat grain by Fusarium spp. and mycotoxin content as dependent on a wheat variety, crop rotation, a crop management system and weather conditions. Food Addit. Contam. 32:874-910.

De Wolf ED, Madden LV, Lipps PE, 2003. Risk assessment models for wheat Fusarium head blight epidemics based on within season weather data. Phytopathology 93:428-35.

European Commission, 2006a. Commission regulation of 19 December 2006 setting maximum levels for certain contaminants in foodstuffs, 1881/2006/EC. In: Official Journal, L $364 / 5,20 / 12 / 2006$, pp. 5-24.
European Commission, 2006b. Commission regulation of 23 February 2006 laying down the methods of sampling and analysis for the official control of the levels of mycotoxins in foodstuffs, 401/2006/EC. In: Official Journal, L 70, pp. 12-34.

European Commission, 2007. Commission regulation of 28 September 2007 amending Regulation (EC) No 1881/2006 setting maximum levels for certain contaminants in foodstuffs as regards Fusarium toxins in maize and maize products, 1126/2007/EC. In: Official Journal, L 255/14, 29/09/2007, pp. 14-17.

Fedak G, Cao W, Xue A, Savard M, Clarke J, Somers DJ, 2007. Enhancement of Fusarium head blight resistance in bread wheat and durum by means of wide crosses. In: H.T. Buck (Ed.), Proc. of the $7^{\text {th }}$ International Wheat Conference, 27 November-2 December 2005, Mar del Plata, Argentina Wheat production in stressed environments. Springer, 12:91-95.

Foround NA, Eudes F, 2009. Trichothecenes in cereal grains. Int. J. Mol. Sci. 10:147-73.

Gauthier T, Waché Y, Laffitte J, Taranu I, Saeedikouzehkonani N, Mori Y, Oswald IP, 2013. Deoxynivalenol impairs the immune functions of neutrophils. Mol. Nutr. Food Res. 57:1026-36.

Jauhar PP, Peterson TS, 2009. Chromosome engineering of durum wheat with alien chromatin of diploid wheatgrass. J. Crop Improv. 23:319-31.

Ji F, Wu J, Zhao H, Xu J Shi J, 2015. Relationship of deoxynivalenol content in grain, chaff, and straw with Fusarium head blight severity in wheat varieties with various levels of resistance. Toxins 7:728-42.

Kang Z, Buchenauer H, 2000. Ultrastructural and immunocytochemical investigation of pathogen development and host responses in resistant and susceptible wheat spikes infected by Fusarium culmorum. Physiol. Mol. Plant Pathol. 57:255-68.

Kelly A C, Clear RM, O’Donnell K, McCormick S, Turkington TK, Tekauz A, Gilbert J, Kistler HC, Busman M, Ward TJ, 2015. Diversity of Fusarium head blight populations and trichothecene toxin types reveals regional differences in pathogen composition and temporal dynamics. Fungal Genet. Biol. 82:22-31.

Kluger B, Bueschl C, Lemmens M, Michlmayr H, Malachova A, Koutnik A, Maloku I, Berthiller F, Adam G, Krska R, Schumacher R, 2015. Biotrasformation of the mycotoxin deoxynivalenol in Fusarium resistant and susceptible near isogenic wheat lines. PLoS One 10:e0119656.

Krska R, Kluger B, Büschl C, Warth B, Berthiller F, Adam G, Schuhmacher R, Sulyok M, 2014. Multi-toxin testing in food and urine-present and future of an amazing approach. International Mycotoxin Conference 2014, 18-23 May, Beijing, P.R.C. Book of Abstracts 93.

Lemmens M, Scholz U, Berthiller F, Dall'Asta C, Koutnik A, Schuhmacher R, Adam G, Buerstmayr H, Mesterházy Á, Krska, R, Ruchenbauer P, 2005. The ability to detoxify the mycotoxin deoxynivalenol colocalizes with a major quantitative trait locus for Fusarium head blight resistance in wheat. Mol. Plant-Microb. Inter. 18:1318-24.

Lionetti V, Giancaspro A, Fabri E, Giove SL, Reem N, Zabotina OA, Blanco A, Gadaleta A, Bellincampi D, 2015. Cell wall traits as potential resources to improve resistance of durum wheat against Fusarium graminearum. BMC Plant Biol. 15:6.

Lori GA, Sisterna MN, Sarandón SJ, Rizzo I, Chidichimo H, 2009. Fusarium head blight in wheat: impact of tillage and other agronomic practices under natural infection. Crop Prot. 28:495-502.

Magan N, Hope R, Colleate A, Baxter ES, 2002. Relationship 
between growth and mycotoxin production by Fusarium species, biocides and environment. Eur. J. Plant Pathol. 108:685-90.

Maresca M, 2013. From the gut to the brain: journey and pathophysiological effects of the food-associated trichothecene mycotoxin deoxynivalenol. Toxins 5:784-820.

Pierron A, Mimoun S, Murate LS, Loiseau N, Lippi Y, Bracarense AP, Liaubet L, Schatzmayr G, Berthiller F, Moll WD, Oswald IP, 2016. Intestinal toxicity of the masked mycotoxin deoxynivalenol-3- $\beta$-D-glucoside. Arch. Toxicol. Aug. 90:2037-46.

Pinton F, Oswald IP, 2014. Effect of deoxynivalenol and other Type B trichothecenes on the intestine: A review. Toxins 6:1615-43.

Quaranta F, Amoriello T, Aureli G, Belocchi A, D'Egidio MG, Fornara M, Melloni S, Desiderio E, 2010. Grain yield, quality and deoxynivalenol (DON) contamination of durum wheat (Triticum durum Desf.): results of national networks in organic and conventional cropping systems. Ital. J. Agron. 5:361-74.

Quaranta F, Belocchi A, Fornara M, Ripa C, D’Egidio MG, 2013. Le varietà di frumento duro in Italia. Risultati della rete nazionale di sperimentazione 1999-2012. Council for Agricultural Research and Economics, Rome, Italy.

Rocha O, Ansari K, Doohan FM, 2005. Effects of trichothecene mycotoxins on eukaryotic cells: A review. Food Addit. Contam. 22:369-78.

Ruan Y, Comeau A, Langevin F, Hucl P, Clarke JM, Brule-Baqbel
A, Pozniak CJ, Gulick P, 2012. Identification of novel QTL for resistance to Fusarium head blight in a tetraploid wheat population. Genome 55:853-64.

SCF, 2002. Opinion on Fusarium toxins. Part 6: Group evaluation of T-2 toxin, HT-2 toxin, nivalenol and deoxynivalenol. Available from: https://ec.europa.eu/food/sites/food/files/safety/docs/sci-com_scf_out123_en.pdf

Stanic A, Uhlig S, Rise F, Miles CO, 2014. Understanding the reaction of deoxynivalenol with model and biologically relevant nucleophiles. International Mycotoxin Conference 2014, 18-23 May, Beijing, P.R.C. Book of Abstracts 136.

Walter S, Kahla A, Arunachalam C, Perochon A, Khan MR, Scofield SR, Doohan FM, 2015. A wheat ABC transporter contributes to both grain formation and mycotoxin tolerance. J. Experim. Bot. 66:2583-93.

Wegulo SN, 2012. Factors influencing deoxynivalenol accumulation in small grain cereals. Toxins 4:1157-80.

$\mathrm{Xu} X, 2003$. Effects of environmental conditions on the development of Fusarium ear blight. Eur. J. Plant Pathol. 109:683-9.

Yazar, S, Omurtag, GZ, 2008. Fumonisins, trichothecenes and zearalenone in cereals. Int. J. Mol. Sci. 9:2062-90.

Zachariasova M, Hajslova J, Kostelanska M, Poustka J, Krplova A, Cuhra P, Hochel I, 2008. Deoxynivalenol and its conjugates in beer: a critical assessment of data obtained by enzyme-linked immunosorbent assay and liquid chromatography coupled to tandem mass spectrometry. Anal. Chim. Acta 625:77-86. 